\title{
In Vitro Properties of Mycobacterium lepraemurium Strain Keishicho
}

\author{
HAJIME SAITO, KOJI YAMAOKA, AND KATSUHIRO KIYOTANI \\ Department of Bacteriology, Hiroshima University School of Medicine, Hiroshima 734, Japan
}

The morphologic, biochemical, and drug susceptibility characteristics of the Keishicho strain, supposedly a strain of Mycobacterium lepraemurium, are compared with these same characteristics of representative strains of other slowgrowing mycobacterial species. The Keishicho strain is quite distinct from all other mycobacteria. Special media and very large inocula are needed for in vitro growth; growth is exceedingly slow. The inter-taxon similarity coefficients were low; the highest, only $63 \%$, was to Mycobacterium tuberculosis.

Mycobacterium lepraemurium was discovered by Stefansky in 1903 (16). Since then many attempts in Japan and other countries have been made to culture this bacterium in cell-free media, but few have been successful.

In 1970, Ogawa and Motomura (9) and, in 1972, Ogawa and Hiraki (7) reported that they were successful in isolating extremely slowgrowing, acid-fast bacilli from mice infected with Hawaiian and Keishicho strains of $M$. lepraemurium, respectively, and that serial culturing was achieved using $1 \%$ egg yolk medium. Further, Ogawa and co-workers (7-10), using these isolates, studied some of the in vitro characteristics and tests for reproduction of the disease in mice and achieved findings which suggest that these isolates are $M$. lepraemurium. Koseki and co-workers (4) and Mori (6) have confirmed the reports of Ogawa and coworkers (7-10). Recently, Mori (personal communication) was successful in isolating from heavily infected mice six strains (Douglas, Odessa, Osaka, Fukuoka, Kurume, and Kumamoto) similar to the Hawaiian and Keishicho strains of $M$. lepraemurium.

The present study was carried out to determine the biological and biochemical characteristics of strain Keishicho and to make comparisons with known representatives of other slowgrowing mycobacterial species.

\section{MATERIALS AND METHODS}

Bacterial strains. The bacterial strains used in this study are listed in Table 1 . The Keishicho strain had been serially transferred 13 times on $1 \%$ egg yolk medium (9) by T. Ogawa, Kitasato Institute, Tokyo, Japan; after receipt from him, five to seven additional passages were made. The composition of $1 \%$ egg yolk medium is as follows: basic solution (1\% sodium glutamate and $\left.1 \% \mathrm{KH}_{2} \mathrm{PO}_{4}\right), 100 \mathrm{ml}$; egg yolk, $200 \mathrm{ml}$; glycerol, $6 \mathrm{ml} ; 2 \%$ malachite green solution, $6 \mathrm{ml}$. For each test tube ( 15 by $150 \mathrm{~mm}$ ) an 8-ml volume was inspissated in a slanted position at $90 \mathrm{C}$ for $1 \mathrm{~h}$. The $\mathrm{pH}$ was 6.0 to 6.2 . Tube closure was with a rubber stopper (Nissui Pharmaceutical Co., Tokyo) with an opening for ventilation. The Keishicho strain was cultured for 4 to 5 weeks; the other strain was cultured for 2 weeks. $M$. marinum and $M$. ulcerans strains were incubated at $30 \mathrm{C}$; the other strains were incubated at $37 \mathrm{C}$.

Colony characteristics. Roughness or smoothness of the colony was determined by whether or not a loopful of bacteria which had been triturated on the inner wall of a test tube produced a homogeneous suspension in saline. The color of colonies was checked by first observing the pigment in bacteria cultured in dark places, followed by exposing them to light for $1 \mathrm{~h}$, and then studying the degree of pigment intensification after overnight incubation at $37 \mathrm{C}$. The iron uptake of the colonies was determined by inoculating a loopful of bacteria onto $1 \%$ egg yolk medium containing $2 \%$ ferric ammonium citrate, and examination for intense rust color in the colonies was made after 8 weeks for the Keishicho strain and after 4 weeks for all other bacteria.

Inocula and growth at different temperatures. The Keishicho strain was found to grow only when a loopful of dry bacterial mass (not a suspension) was used as inoculum. Consequently, in addition to inoculation with a loopful of saline suspension $(1 \mathrm{mg} / \mathrm{ml})$, as used for all other strains, a loopful of dry bacterial mass of the Keishicho strain was regularly used to inoculate control and test media. For testing growth at different temperatures, replicate tubes of inoculated $1 \%$ egg yolk medium were incubated at $30,37,42$, and $45 \mathrm{C}$.

Resistance tests. Resistance to pyronine was determined using a modified 1\% egg yolk medium without malachite green but supplemented with $0.03 \%$ pyronine (Grübler \& Co., Germany). For 250 and $500 \mu \mathrm{g}$ of $p$-nitrobenzoic acid per ml (PNB; Tokyo Kasei Co., Tokyo), the egg medium described by Tsukamura (18) from which the egg white was omitted was used.

Resistance to the following chemicals was determined by adding the indicated amounts to $1 \%$ egg yolk medium: $0.5 \%$ nicotinamide (Katayama Chemical Co., Osaka, Japan); $0.5 \%$ sodium deoxycholate 
TABLE 1. Strains used ${ }^{a}$

\begin{tabular}{|c|c|c|}
\hline Species & Strains & Received from \\
\hline $\begin{array}{l}\text { Mycobacterium leprae- } \\
\text { murium }\end{array}$ & Keishicho & T. Ogawa, Kitasato Institute, Tokyo, Japan \\
\hline M. tuberculosis & H37Rv & H. Shoji, Osaka University, Osaka, Japan \\
\hline M. bovis & Ravenel & M. Tsukamura, Chubu Chest Hospital, Aichi, Japan \\
\hline M. microti & D-15 & H. Takahashi, National Institute of Health, Tokyo, Japan \\
\hline M. kansasii & ATCC 12478 & American Type Culture Collection, Rockville, Md. \\
\hline M. marinum & ATCC 927 & American Type Culture Collection, Rockville, Md. \\
\hline M. marianum & ATCC 19981 & M. Tsukamura, Chubu Chest Hospital, Aichi, Japan \\
\hline$M$. gordonae & ATCC 14470 & M. Tsukamura, Chubu Chest Hospital, Aichi, Japan \\
\hline M. avium & ATCC 15769 & American Type Culture Collection, Rockville, Md. \\
\hline M. intracellulare & ATCC 15985 & $\begin{array}{l}\text { E. H. Runyon, Veterans Administration Hospital, Salt } \\
\text { Lake City, Utah }\end{array}$ \\
\hline M. xenopi & ATCC 19250 & M. Tsukamura, Chubu Chest Hospital, Aichi, Japan \\
\hline M. ulcerans & P.D. & H. Takahashi, National Institute of Health, Tokyo, Japan \\
\hline M. gastri & ATCC 15754 & $\begin{array}{l}\text { L. G. Wayne, Veterans Administration Hospital, San Fer- } \\
\text { nando, Calif. }\end{array}$ \\
\hline M. nonchromogenicum & ATCC 19530 & M. Tsukamura, Chubu Chest Hospital, Aichi, Japan \\
\hline
\end{tabular}

${ }^{a}$ ATCC, American Type Culture Collection.

(Difco); $0.1 \%$ sodium nitrite (Katayama Chemical Co., Osaka, Japan); $3 \%$ sodium chloride; 10 and 20 $\mu \mathrm{g}$ of sodium azide per $\mathrm{ml}$ (Kanto Chemical Co., Tokyo); 1, 5, and $10 \mu \mathrm{g}$ of 2-furoic acid hydrazide per $\mathrm{ml}$ (FAH, Aldrich Chemical Co.); 125, 250, and 500 $\mu \mathrm{g}$ of $\mathrm{NH}_{2} \mathrm{OH}-\mathrm{HCl}$ per ml (Katayama Chemical Co., Osaka, Japan); and 250, 500, and 1,000 $\mu$ g of sodium salicylate per ml (Katayama Chemical Co., Osaka, Japan). All cultures to be tested were inoculated and observed in the same manner as described above.

Biochemical characteristics. The following tests were performed by the procedure outlined in the references listed: neutral red (3); niacin (13); Tween 80 hydrolysis (21); nitrate reduction (20); acid phosphatase (19); pH 5.0/70 C acid phosphatase (14); arylsulfatase (17); semiquantitative catalase (22); $\mathrm{pH}$ 7.0/68 C catalase (5); diamine (cadaverine, propylenediamine, and putrescine)-oxydase (2); and Bönicke's amidase series (1).

Determination of similarity values. Calculations of the similarity (S) values between the strains examined were based on the Adansonian principles described by Sneath (15) and involved dividing the number of similarities by the total number of comparisons. $S$ values are given as percentages in the present work. The 52 properties used in characterizing the organisms are listed in Table 2.

\section{RESULTS}

Description of strain Keishicho. Inoculation of a $1 \mathrm{mg} / \mathrm{ml}$ suspension onto egg yolk medium failed to produce visible growth of the organism. When a loopful of dry growth was triturated onto this medium, rough non-photochromogenic colonies were produced, but the growth was very slow. On 1\% Ogawa egg medium, the inoculated bacterial masses absorbed the malachite green in the medium and became green, but no increase in size was found (recorded as no growth).
Organisms inoculated onto culture media which contained $0.5 \%$ nicotinamide, $0.5 \%$ sodium deoxycholate, $0.1 \%$ sodium nitrite, $3 \%$ sodium chloride, $20 \mu \mathrm{g}$ of sodium azide, $500 \mu \mathrm{g}$ of PNB, 125,250 , or $500 \mu \mathrm{g}$ of $\mathrm{NH}_{2} \mathrm{OH}-\mathrm{HCl}$, or 250,500 , or $1,000 \mu \mathrm{g}$ of sodium salicylate revealed dried whitish yellow or green masses, but no increase in size compatible with growth was observed. On cultures which contained $0.03 \%$ pyronine, $10 \mu \mathrm{g}$ of sodium azide, 1,5 , and $10 \mu \mathrm{g}$ of $\mathrm{FAH}$, and $250 \mu \mathrm{g}$ of PNB, respectively, all showed growth almost as good as on control media.

The organism was negative in niacin production, nitrate reduction, arylsulfatase, Tween hydrolysis, acid phosphatase, $70 \mathrm{C}$ acid phosphatase, and diamine-oxydase tests. It did demonstrate comparatively strong neutral red reaction and low catalase activity (less than $10 \mathrm{~mm}$ of foam produced), which was inactivated at $68 \mathrm{C}$. Of Bönicke's amidase series, only nicotinamidase and pyrazinamidase were positive, whereas all others were negative. See Table 2 for full tabulation of results.

Similarity values. The inter-taxon percent similarity values of the test strains are shown in Table 3. The Keishicho strain exhibited low inter-taxon $S$ values for all species, the highest being $M$. tuberculosis (63\%) followed by $M$. avium (54\%). M. microti, M. bovis, M. xenopi, $M$. marinum, $M$. nonchromogenicum, $M$. marianum ( $M$. scrofulaceum), and $M$. kansasii showed inter-taxon $S$ values ranging from 41 to $48 \%$, whereas $M$. intracellulare, $M$. gordonae, $M$. ulcerans, and $M$. gastri had values of only 29 to $38 \%$. The inter-taxon $\mathrm{S}$ values between other strains tested were all low, and none exceeded $76 \%$. 
TABLE 2. Characterization of Keishicho strain of $M$. lepraemurium and comparison with a representative strain of each of several other slow-growing mycobacterial species

\begin{tabular}{|c|c|c|c|c|c|c|c|c|c|c|c|c|c|c|}
\hline Characteristics & 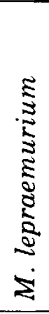 & 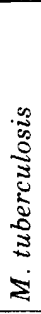 & 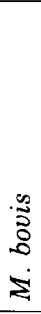 & 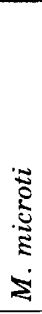 & 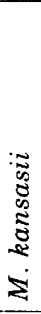 & 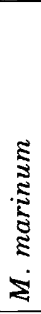 & 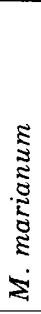 & 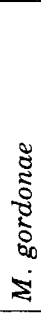 & $\begin{array}{l}\tilde{5} \\
\mathbf{z} \\
\tilde{z} \\
0 \\
\Sigma\end{array}$ & 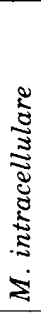 & 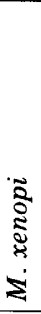 & 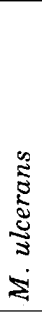 & 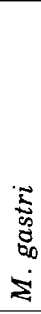 & 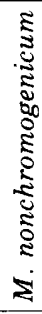 \\
\hline Colony morphology ${ }^{a}$ & $\mathbf{R}$ & $\mathrm{R}$ & $\mathrm{R}$ & $\mathrm{R}$ & $\mathbf{S}$ & $\mathrm{S}$ & $\mathrm{S}$ & $\mathrm{S}$ & $\mathrm{S}$ & $\mathrm{S}$ & $\mathbf{S}$ & $\mathbf{S}$ & $\mathbf{S}$ & $\mathbf{S}$ \\
\hline Pigment production: & & & & & & & & & & & & & & \\
\hline In dark & - & - & - & - & - & - & + & + & - & - & + & - & - & - \\
\hline Stimulation by light $(1 \mathrm{~h})$ & - & - & - & - & + & + & - & - & - & - & - & - & - & - \\
\hline Growth at: & & & & & & & & & & & & & & \\
\hline $30 \mathrm{C}$ & + & + & + & + & + & + & + & + & + & + & + & + & + & + \\
\hline $37 \mathrm{C}$ & + & + & + & + & + & + & + & + & + & + & + & - & + & + \\
\hline $42 \mathrm{C}$ & - & - & - & - & + & - & - & - & + & + & + & - & - & - \\
\hline $45 \mathrm{C}$ & - & - & - & - & - & - & - & - & + & - & + & - & - & - \\
\hline Growth on $1 \%$ Ogawa egg medium & - & + & + & + & + & + & + & + & + & + & + & + & + & + \\
\hline $\begin{array}{l}\text { Growth on } 1 \% \text { egg yolk medium by } \\
\text { inoculation with: }\end{array}$ & & & & & & & & & & & & & & \\
\hline Bacterial mass & + & + & + & + & + & + & + & + & + & + & + & + & + & + \\
\hline Bacterial suspension & - & + & + & + & + & + & + & + & + & + & + & + & + & + \\
\hline Growth in presence of: & & & & & & & & & & & & & & \\
\hline 2-Fuoric acid hydrazide $(1 \mu \mathrm{g} / \mathrm{ml})$ & + & + & - & - & + & + & + & + & + & + & + & + & - & + \\
\hline 2-Fuoric acid hydrazide $(5 \mu \mathrm{g} / \mathrm{ml})$ & + & + & - & - & + & + & + & + & + & + & + & + & - & + \\
\hline 2-Fuoric acid hydrazide $(10 \mu \mathrm{g} / \mathrm{ml})$ & + & + & - & - & + & + & + & + & + & + & + & + & - & + \\
\hline Nicotinamide $(0.5 \%)$ & - & - & - & - & - & + & - & - & + & + & - & - & - & + \\
\hline Sodium deoxycholate $(0.5 \%)$ & - & - & - & + & + & + & + & + & + & + & + & + & - & + \\
\hline Sodium chloride $(3 \%)$ & - & - & - & - & - & + & - & - & - & - & - & - & - & - \\
\hline Sodium nitrite $(0.1 \%)$ & - & - & - & - & - & - & - & - & - & + & - & - & - & + \\
\hline Sodium azide $(10 \mu \mathrm{g} / \mathrm{ml})$ & + & + & + & + & + & + & + & + & + & + & + & + & + & + \\
\hline Sodium azide $(20 \mu \mathrm{g} / \mathrm{ml})$ & - & - & - & - & - & - & - & - & - & - & - & - & - & - \\
\hline $\mathrm{NH}_{2} \mathrm{OH}-\mathrm{HCl}(125 \mu \mathrm{g} / \mathrm{ml})$ & - & - & - & - & + & + & + & + & + & + & + & + & + & + \\
\hline $\mathrm{NH}_{2} \mathrm{OH}-\mathrm{HCl}(250 \mu \mathrm{g} / \mathrm{ml})$ & - & - & - & - & - & + & + & - & - & + & - & - & - & + \\
\hline $\mathrm{NH}_{2} \mathrm{OH}-\mathrm{HCl}(500 \mu \mathrm{g} / \mathrm{ml})$ & - & - & - & - & - & - & - & - & - & + & - & - & - & - \\
\hline Sodium salicylate $(250 \mu \mathrm{g} / \mathrm{ml})$ & - & - & - & - & + & + & + & + & + & + & + & - & + & + \\
\hline Sodium salicylate $(500 \mu \mathrm{g} / \mathrm{ml})$ & - & - & - & - & + & + & + & - & + & + & - & - & - & - \\
\hline Sodium salicylate $(1,000 \mu \mathrm{g} / \mathrm{ml})$ & - & - & - & - & - & - & - & - & - & + & - & - & - & - \\
\hline$p$-Nitrobenzoate $(250 \mu \mathrm{g} / \mathrm{ml})$ & + & - & - & - & + & - & + & + & + & + & - & - & - & + \\
\hline$p$-Nitrobenzoate $(500 \mu \mathrm{g} / \mathrm{ml})$ & - & - & - & - & - & - & + & + & - & + & - & - & - & - \\
\hline Pyronine $(0.03 \%)$ & + & + & + & + & + & + & - & - & + & - & - & - & + & + \\
\hline Iron uptake & - & - & - & - & - & - & - & - & - & - & - & - & - & - \\
\hline Neutral red test & + & + & + & + & + & + & - & - & + & - & + & - & - & + \\
\hline Niacin production & - & + & - & + & - & - & - & - & - & - & - & - & - & - \\
\hline Catalase (mm foam) & & & & & & & & & & & & & & \\
\hline$<10 \mathrm{~mm}$ & + & + & + & + & + & + & + & - & + & + & + & - & + & - \\
\hline$>20 \mathrm{~mm}$ & - & - & - & - & - & - & - & + & - & - & - & + & - & + \\
\hline $68 \mathrm{C}$ catalase & - & - & - & - & + & + & + & + & + & + & + & + & - & + \\
\hline Nitrate reduction & - & + & - & + & + & - & - & - & - & - & - & - & - & + \\
\hline Acid phosphatase & - & - & - & - & + & + & - & - & - & + & - & - & + & + \\
\hline $70 \mathrm{C}$ acid phosphatase & - & - & - & - & + & + & - & - & - & - & - & - & + & + \\
\hline Tween 80 hydrolysis (14 days) & - & - & - & - & + & - & - & + & - & - & - & - & + & + \\
\hline Arylsulfatase & - & - & - & + & + & - & + & + & - & + & + & - & + & + \\
\hline Putrescine-oxydase & - & - & - & - & - & + & - & - & - & - & - & - & - & - \\
\hline Cadaverine-oxydase & - & - & - & - & - & - & - & - & - & - & - & - & - & - \\
\hline Propylenediamine-oxydase & - & - & - & - & - & - & - & - & - & - & - & - & - & - \\
\hline Acetamidase & - & - & - & - & - & - & - & - & - & - & - & - & - & - \\
\hline Benzamidase & - & - & - & - & - & - & - & - & - & - & - & - & - & - \\
\hline Urease & - & + & + & + & + & + & + & - & - & - & - & + & + & - \\
\hline Isonicotinamidase & - & - & - & - & - & - & - & - & - & - & - & - & - & - \\
\hline
\end{tabular}


TABLE 2-Continued

Nicotinamidase

Pyrazinamidase

Salicylamidase

Allantoinase

Succinamidase

Malonamidase

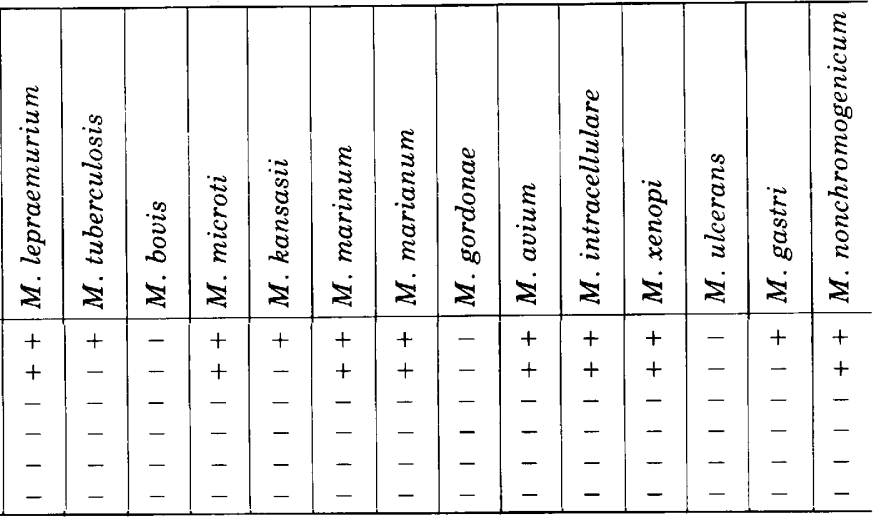

${ }^{a} \mathrm{R}$, Rough; S, smooth.

\section{DISCUSSION}

Characteristics of the Keishicho strain, supposedly a strain of $M$. lepraemurium, growing only when inoculated on $1 \%$ egg yolk medium (9) and not on 1\% Ogawa egg medium (11), were confirmed in this study by use of a culture passed serially 18 to 20 times. For the serial culturing of the strain, a loopful of bacteria was gently placed upon the medium; however, as good results were obtained from smear inoculation of a loopful of bacteria upon the medium, we used the latter method of inoculation.

The organism is an acid-fast bacterium belonging to Runyon Group III (12); it yields rough type growth with an optimum growth temperature of $37 \mathrm{C}$, but its growth was the slowest of all the slow-growing mycobacterial species tested.

The resistance pattern of the Keishicho strain to such chemicals as FAH, nicotinamide, sodium chloride, sodium deoxycholate, sodium nitrite, sodium azide, $\mathrm{NH}_{2} \mathrm{OH}-\mathrm{HCl}$, sodium salicylate, PNB, and pyronine closely resembled that of the $M$. tuberculosis complex, particularly M. tuberculosis.

We have corroborated the findings of Ogawa and Hiraki (7) and Koseki et al. (4) that the bacterium is negative in niacin, $68 \mathrm{C}$ catalase, nitrate reduction, and Tween hydrolysis tests, and weakly positive in the catalase test at room temperature. We further demonstrated that the organism is negative in acid phosphatase, $70 \mathrm{C}$ acid phosphatase, and diamine-oxydase tests but is positive in nicotinamidase, pyrazin-

TABLE 3. Inter-taxon $S$ values of slow-growing mycobacterial species ${ }^{a}$

\begin{tabular}{|c|c|c|c|c|c|c|c|c|c|c|c|c|c|c|c|}
\hline Species & & 1 & 2 & 3 & 4 & 5 & 6 & 7 & 8 & 9 & 10 & 11 & 12 & 13 & 14 \\
\hline Mycobacterium lepraemurium & 1 & 100 & & & & & & & & & & & & & \\
\hline M. tuberculosis & 2 & 63 & 100 & & & & & & & & & & & & \\
\hline M. bovis & 3 & 47 & 65 & 100 & & & & & & & & & & & \\
\hline M. microti & 4 & 48 & 70 & 65 & 100 & & & & & & & & & & \\
\hline M. kansasii & 5 & 41 & 54 & 36 & 47 & 100 & & & & & & & & & \\
\hline M. marinum & 6 & 43 & 47 & 36 & 42 & 69 & 100 & & & & & & & & \\
\hline M. marianum & 7 & 42 & 43 & 31 & 43 & 60 & 63 & 100 & & & & & & & \\
\hline M. gordonae & 8 & 32 & 35 & 26 & 29 & 53 & 39 & 68 & 100 & & & & & & \\
\hline M. avium & 9 & 54 & 48 & 36 & 46 & 67 & 67 & 64 & 50 & 100 & & & & & \\
\hline M. intracellulare & 10 & 38 & 33 & 23 & 33 & 59 & 59 & 72 & 55 & 67 & 100 & & & & \\
\hline M. xenopi & 11 & 46 & 46 & 33 & 46 & 60 & 55 & 69 & 60 & 76 & 60 & 100 & & & \\
\hline M. ulcerans & 12 & 29 & 43 & 33 & 30 & 43 & 43 & 50 & 60 & 44 & 38 & 48 & 100 & & \\
\hline M. gastri & 13 & 30 & 43 & 53 & 52 & 62 & 48 & 44 & 36 & 39 & 39 & 42 & 33 & 100 & \\
\hline M. nonchromogenicum & 14 & 43 & 42 & 27 & 42 & 69 & 66 & 55 & 59 & 61 & 64 & 55 & 39 & 48 & 100 \\
\hline
\end{tabular}

${ }^{a}$ Each species is represented by one strain. 
amidase, and neutral red reaction.

The extreme slowness of growth and the requirements of a special medium and very large inocula sufficiently distinguish the Keishicho strain from all other mycobacterial species. The highest percent similarity of any of other strain from all other mycobacterial strains. The highest percent similarity of any other strains to the Keishicho strain was registered by $M$. tuberculosis, which gave a value of $63 \%$.

As judged by the Keishicho strain, $M$. lepraemurium is very different from strains of other species of mycobacteria grown in vitro. Further studies are needed on the other seven strains of $M$. lepraemurium mentioned in the introduction.

\section{ACKNOWLEDGMENTS}

We thank Tatsuji Ogawa and Hiroshi Takahashi for supplying the cultures used in this study.

\section{REPRINT REQUESTS}

Address reprint requests to: Dr. Hajime Saito, Department of Bacteriology, Hiroshima University School of Medicine, Hiroshima 734, Japan.

\section{LITERATURE CITED}

1. Bönicke, R. 1962. Identification of mycobacteria by biochemical methods. Bull. Int. Union Tuberc. 27:13-68.

2. Bönicke, R., and H. Nolte. 1967. Diamin-oxydasen in Mycobakterien. I. Mitteilung: Möglichkeiten der Differenzierung einiger Mycobacterium-Arten mit Hilfe des Diamin-oxydase-Nachweises. Zentralbl. Bakteriol. Parasitenkd. Infektionskr. Hyg. Abt. 1 Orig. 202:479-487.

3. Konno, K. 1962. Biochemical classification of mycobacteria (in Japanese). Nippon Rinsho 20:1736-1748.

4. Koseki, Y.. S. Okamoto, and T. Anchi. 1972. Ogawa's bacillus: slow growing mycobacteria isolated from mice previously infected with murine leprosy bacillus. II. Drug susceptibility and some differential characteristics in vitro (in Japanese). La Lepro 41:137-148.

5. Kubica, G. P., and G. L. Pool. 1960. Studies on the catalase activity of acid-fast bacilli. I. An attempt to subgroup these organisms on the basis of their catalase activities at different temperatures and $\mathrm{pH}$. Am. Rev. Respir. Dis. 81:387-391.

6. Mori, T. 1974. Cultivation of M. lepraemurium on the $1 \%$ Ogawa yolk medium and animal inoculation with cultivated $M$. lepraemurium (in Japanese). La Lepro 43:266-233.

7. Ogawa, T., and M. Hiraki. 1972. Studies on murine leprosy bacillus. VI. Attempt to cultivate in vitro of one other strain of Mycobacterium lepraemurium: pri- mary isolation of slow growing mycobacteria from mice previously inoculated with Keishicho strain. Kitasato Arch. Exp. Med. 43:147-155.

8. Ogawa, T., and M. Hiraki. 1972. Studies on murine leprosy bacillus. VII. Temperature range and temperature optimum for the growth of the supposed murine leprosy bacillus. Kitasato Arch. Exp. Med. 45:157163.

9. Ogawa, T., and K. Motomura. 1970. Studies on murine leprosy bacillus. I. Attempt to cultivate in vitro the Hawaiian strain of Mycobacterium lepraemurium. Kitasato Arch. Exp. Med. 43:65-80.

10. Ogawa, T., and K. Motomura. 1971. Studies on murine leprosy bacillus. IV. Attempt to cultivate in vitro the Hawaiian strain of Mycobacterium lepraemurium: the $\mathrm{fi}$ rther report on primary in vitro isolation, subcultivation, reproduction test of the disease in mice of slow growing acid-fast organisms, supposedly murine leprosy bacillus. Kitasato Arch. Exp. Med. 44:167183.

11. Ogawa, T., and K. Sawa. 1949. The quantitative culture method for tubercle bacilli: on the case of cultivation of bacterial suspension (in Japanese). Kekkaku 24:13-18.

12. Runyon, E. H. 1959. Anonymous mycobacteria in pulmonary disease. Med. Clin. N. Am. 43:273-290.

13. Runyon, E. H., M. J. Selin, and H. W. Harris. 1959 Distinguishing mycobacteria by the niacin test. A modified procedure. Am. Rev. Respir. Dis. 79:663665 .

14. Saito, H., H. Hosokawa, and H. Tasaka. 1967. The heat stable acid phosphatase activity of mycobacteria. Am. Rev. Respir. Dis. 97:474-476.

15. Sneath, P. H. A. 1957 . The application of computers to taxonomy. J. Gen. Microbiol. 17:201-226.

16. Stefansky, W. K. 1903. Eine lepraähnliche Erkrankung der Haut und der Lymphdrüsen bei Wanderratten. Zentralbl. Bakteriol. Parasitenkd. Infektionskr. Hyg. Abt. 1 Orig. 33:481-487.

17. Tarshis, M. S. 1964. A rapid 24-hour micro-phenolphthalein sulfatase test for distinguishing $M$. avium from the unclassified Battey bacilli. An improved procedure. Acta Tuberc. Scand. 45:221-229.

18. Tsukamura, M. 1964. Differentiation of Mycobacterium tuberculosis and Mycobacterium bovis by p-nitrobenzoic acid susceptibility. Tubercle 45:64-65.

19. Urabe, K., H. Saito, H. Tasaka, and A. Matsubayashi. 1966. The acid phosphatase activity of mycobacteria and a simple method for its detection (in Japanese). Med. Biol. 72:127-130.

20. Virtanen, S. 1960. A study of nitrate reduction by mycobacteria: the use of the nitrate reduction test in the identification of mycobacteria. Acta Tuberc. Scand. Suppl. 48:1-119

21. Wayne, L. G. 1962 . Differentiation of mycobacteria by their effect on Tween $\otimes 80$. Am. Rev. Respir. Dis. 86:579-581.

22. Wayne, L. G. 1962. Two varieties of Mycobacterium kansasii with different clinical significance. Am. Rev. Respir. Dis. 86:651-656. 